\title{
Research on IPO Approval for GEM and International Comparison
}

\author{
HE Jian-ying \\ TUC-FIU Cooperative School, Tianjin University of Commerce, Tianjin, China \\ teacherhjy@126.com
}

\begin{abstract}
Keywords: GEM; IPO Approval; International Comparison
\end{abstract}
\begin{abstract}
October 30, 2009 was the first trading day of the new Growth Enterprises Market (hereinafter, GEM) in Shenzhen. With the rapid growth of GEM, the mechanism of IPO approval has attracted the attention of more and more researchers. As we know, a proper IPO approval is the precondition of the success of GEM. Therefore, we cannot emphasize the importance of impartiality and effectiveness in IPO approval process too much. Based on the considerations, this paper explores the characters of Chinese IPO approval, compares the differences between Chinese IPO approval process and others countries'. Finally, we make empirical study to test the determinants of IPO approval in China GEM. Both qualitative analysis and quantitative analysis are used in the paper.
\end{abstract}

\section{The origin of Chinese GEM}

GEM broad provides the companies who are mainly engaged in the high-tech and pharmaceutical industry opportunity to finance. The performances of those companies are probably not outstanding. They, however, have a high growth potential. The most remarkable feature of GEM is the low barriers to be listed. It therefore has the potential to help young companies to access new capital.

On the policy front, in 2004 the State Council published Some Opinions on Reform, Opening and Steady Growth of Capital Markets ("the Nine Opinions"), in which the concept of a "multi-tier capital market" was presented for the first time. A first step in this direction was made in the same year, when an SME Board was established as part of the Main Board. Although there appear to have been plans to eventually relax the SME Board's listing requirements, which were the same as those for companies listed on the Main Board, and to make it a market especially for venture businesses, it was decided to establish a separate market (the Second Board) for this purpose and to learn from the experience of the SME Board.

On March 31, 2009, the China Securities Regulatory Commission (“CSRC”) issued the "Interim Measures for the initial public offerings and listing on the Second Board". They came into effect on May 1, 2009. The Measures are the basic act for the Second Board and include detailed provisions on the conditions of issue, issuing procedures, information disclosure, supervision management, legal liability and other aspects.

The Shenzhen Stock Exchange issued the "Shenzhen Stock Exchange Second Board Stock Listing Rules" ("ChiNext Listing Rules”), which contain provisions on the Company's information disclosure, sponsors, the board of directors, resolution of board of supervisors, suspension, resumption and termination of listing. They came effective on July 1, 2009.

\section{The differences between Chinese IPO approval and other countries'}

There are two different legal systems worldwide: registration one and approval one. [1]

China Securities Regulatory Commission (hereinafter, CSRC) shall, in accordance with law, examine and approve the issuer's IPO application and supervise the issuer's IPO activities. Therefore approval system is applied in Chinese GEM. While in USA and other developed countries, local companies which would go public face registration system.

With the development of Chinese capital market, it should be a trend to transform approval system to registration one. Media and securities regulators received tip-offs on irregularities and frauds in the 
prospectus for the traditional Chinese medicine maker. When a prospectus is approved, it means securities regulators have already verified the truthfulness of the application. Yet regulators are not motivated to investigate even when there is doubt about the prospectus. Therefore, under the current system, it is hard for regulators to be neutral. It is necessary to have an overhaul of the approval system and adopt stricter investigation procedures to protect the interests of investors. [2]

\section{The international comparison of GEM}

Since its creation in 1971, the NASDAQ has made its mark among financial markets and became a major driving force in our global economy. It has changed the way stocks are traded forever and has been used as a model for many subsequent exchanges around the world. The name NASDAQ stands for National Association of Securities Dealers Automated Quotations. The NASDAQ was created to increase trading in over-the-counter stocks which couldn't meet the requirements necessary to post their listings on larger exchanges such as the New York stock exchange. [3, 4] While these over-the-counter stocks used to be traded by phone and all the information on the stock had to be given by a dealer who was specialized in the stock, access to these stocks was limited to only a few individuals. The public at large had no access to these stocks and it prevented their potential for growth. The NASDAQ was founded in 1971 to allow dealers to post quotes on their stock electronically. This allowed more and more people to gain access to these stocks and gave more visibility to the stocks being traded. The success of the NASDAQ was instant and the NASDAQ started to impose its own listing requirements so they could separate the smaller over-the-counter stocks from the larger stocks. The aim was to help them compete with bigger stock exchanges around the world. [5, 6]The NASDAQ is now the biggest stock exchange by trading volume in the world. The reason why it has been able to reach that plateau in a relatively short period of time is because of the efficiency of their all electronic model. However, the New York stock exchange is still the biggest in the world by market capitalization.

The goal of the market maker is to earn the spread, or the difference between the rates where they're selling a stock to the public versus the rate where they acquire the stock from the public. Various market makers will are competing against each other on the same stocks. The competition between the various market makers in each stock is what will lower transactions costs at the end. This is one of the main reasons why the NASDAQ has gained so much in popularity since its inception. [7]

The NASDAQ is viewed by many as the most efficient market place for traders. The NASDAQ is ever expanding and trying to gain more ground in overseas markets. The NASDAQ is definitely here to stay and only time will tell how high it can go.

\section{A Study on IPO Approval in GEM}

We analyze the determinants of IPO approval in China GEM based on the attributes of the regulatory body, the underwriter, the issuer, and assessed the impartiality and effectiveness of the process, and construct the basic regression model. The research model is binary logistic regression model.

$$
\begin{aligned}
& \text { Alter }=\beta_{0}+\sum_{i=1}^{7} \beta_{1 i} \times \text { Peri }_{i}+\beta_{2} \text { Brep }+\beta_{3} \sum_{i=1}^{4} \beta_{3 i} \times \text { Cont }_{i}+\sum_{i=1}^{10} \beta_{4 i} \times \text { Ind }_{i} \\
& +\sum_{i=1}^{3} \beta_{5 i} \times \text { Loca }_{i}+\beta_{6} \text { Age }+\beta_{7} \text { Pat }+\beta_{8} R \& D+\beta_{9} \text { Pol }+\beta_{10} E d u+\beta_{11} \text { ODD } \\
& +\beta_{12} \text { ODM }+\beta_{13} \text { PE \&VC }+\beta_{14} \text { FAM }+\beta_{15} \text { FIN }+\beta_{16} G R O+\beta_{17} T U R \\
& +\beta_{18} R O A+\beta_{19} L E V+\beta_{20} \text { CAS }+\varepsilon
\end{aligned}
$$

Table 1 shows the descriptive statistics of the variables and the comparison of the mean of the groups. Table 2 shows the results of regression analysis of factors affecting the company's approval. 
Taking the characteristics of the industry assets and other factors into account, this paper uses three models for regression analysis. This paper does not take PAT and R \& D into Model 1. Excluding the 12 companies without R \& D spending, this paper takes the variable R\&D into Model 2. In the Model 3 , after deleting the sample of information, high-tech services and other industries which are usually not holding the patent, the variable PAT and $R \& D$ are taken into the Model 1 as incremental explanatory variables.

Table 1 Descriptive Statistics of Variables and Their Comparison

\begin{tabular}{|c|c|c|c|c|c|c|c|}
\hline & \multicolumn{3}{|c|}{ Approved } & \multicolumn{3}{|c|}{ Not Approved } & \multirow{2}{*}{$\begin{array}{c}\text { Mean } \\
\text { Test }\end{array}$} \\
\hline & Mean & Median & $\begin{array}{l}\text { Standard } \\
\text { Deviation }\end{array}$ & Mean & Median & $\begin{array}{l}\text { Standard } \\
\text { Deviation }\end{array}$ & \\
\hline \multicolumn{8}{|c|}{ All Sample } \\
\hline BREP & 2.474 & 2.000 & 1.257 & 2.189 & 2.000 & 1.101 & 1.428 \\
\hline AGE & 9.453 & 9.125 & 3.248 & 9.942 & 9.190 & 3.646 & -0.789 \\
\hline POL & 0.265 & 0.000 & 0.450 & 0.327 & 0.000 & 0.486 & -0.911 \\
\hline Edu & 3.402 & 3.425 & 0.483 & 3.114 & 3.336 & 0.347 & -0.338 \\
\hline ODD & 0.726 & 0.747 & 0.328 & 0.697 & 0.665 & 0.315 & 0.762 \\
\hline ODM & 0.654 & 0.608 & 0.443 & 0.726 & 0.641 & 0.542 & -0.642 \\
\hline PE\&VC & 6.246 & 1.000 & 0.525 & 0.478 & 0.000 & 0.562 & $2.462 * * *$ \\
\hline FAM & 0.531 & 1.000 & 0.500 & 0.386 & 0.000 & 0.489 & $1.774^{*}$ \\
\hline FIN & 0.426 & 0.438 & 0.081 & 0.417 & 0.418 & 0.035 & -0.813 \\
\hline GRO & 0.543 & 0.375 & 0.569 & 0.425 & 0.379 & 0.311 & 0.923 \\
\hline TUR & 1.116 & 0.997 & 0.453 & 1.054 & 1.002 & 0.448 & 0.044 \\
\hline ROA & 0.219 & 0.205 & 0.103 & 0.214 & 0.187 & 0.112 & 0.358 \\
\hline LEV & 0.449 & 0.452 & 0.136 & 0.427 & 0.413 & 0.178 & 1.115 \\
\hline CAS & 1.012 & 1.127 & 0.121 & 0.976 & 1.004 & 0.132 & 1.249 \\
\hline Sample Number & \multicolumn{3}{|c|}{226} & \multicolumn{3}{|c|}{47} & \\
\hline \multicolumn{8}{|c|}{ Delete the sample that the company's research and development costs 0} \\
\hline $\mathrm{R} \& \mathrm{D}$ & 0.063 & 0.049 & 0.053 & 0.061 & 0.044 & 0.059 & 0.048 \\
\hline Sample Number & \multicolumn{3}{|c|}{216} & \multicolumn{3}{|c|}{45} & \\
\hline \multicolumn{8}{|c|}{ Delete the sample of information, high-tech services and other industries } \\
\hline PAT & 14.765 & 7 & 49.067 & 10.561 & 8 & 9.590 & 0.592 \\
\hline Sample Number & \multicolumn{3}{|c|}{164} & \multicolumn{3}{|c|}{26} & \\
\hline
\end{tabular}

Note: $* * *, * *, *$ respectively, said in $0.01,0.05,0.10$ of the significant level.

From the empirical results of Table 2, we find that reputation of underwriters, shareholdings of $\mathrm{PE} / \mathrm{VC}$, and family control of the firm are positively correlated with the possibility of passing the issuance examination. In contrast, political connections of the chairman or CEO of the firm have a negative impact on the opportunity. Other factors such as financial conditions, funding needs, number of patents, and R\&D expenditures have no significant influence. Further analysis suggest that although there is no evident rent-seeking or regional discrimination in the IPO approval process, it has yet achieved the goal of selecting the most qualified startup companies in GEM. 
Table 2 Analysis of the Factors Affecting the Company's Approval

\begin{tabular}{|c|c|c|c|}
\hline $\begin{array}{l}\text { Explanatory } \\
\text { Variable }\end{array}$ & Model 1 & Model 2 & Model 3 \\
\hline BREP & $\begin{array}{l}0.175^{*} \\
(0.098)\end{array}$ & $\begin{array}{l}0.231^{*} \\
(0.104)\end{array}$ & $\begin{array}{c}0.153 \\
(0.137)\end{array}$ \\
\hline AGE & $\begin{array}{c}0.000 \\
(0.029)\end{array}$ & $\begin{array}{c}0.027 \\
(0.029)\end{array}$ & $\begin{array}{c}0.071 \\
(0.064)\end{array}$ \\
\hline PAT & - & - & $\begin{array}{c}0.005 \\
(0.008)\end{array}$ \\
\hline R\&D & - & $\begin{array}{l}-0.753 \\
(2.449) \\
\end{array}$ & $\begin{array}{l}-3.187 \\
(3.097) \\
\end{array}$ \\
\hline POL & $\begin{array}{l}-0.412 \\
(0.327)\end{array}$ & $\begin{array}{c}-0.553^{* *} \\
(0.265)\end{array}$ & $\begin{array}{l}-0.74 * * \\
(0.332)\end{array}$ \\
\hline Edu & $\begin{array}{l}-0.087 \\
(0.375)\end{array}$ & $\begin{array}{l}-0.045 \\
(0.398)\end{array}$ & $\begin{array}{l}-0.287 \\
(0.479)\end{array}$ \\
\hline ODD & $\begin{array}{c}0.256 \\
(0.304)\end{array}$ & $\begin{array}{c}0.356 \\
(0.373)\end{array}$ & $\begin{array}{c}0.015 \\
(0.504)\end{array}$ \\
\hline ODM & $\begin{array}{l}-0.054 \\
(0.219)\end{array}$ & $\begin{array}{l}-0.070 \\
(0.262)\end{array}$ & $\begin{array}{l}-0.406 \\
(0.398)\end{array}$ \\
\hline PE\&VC & $\begin{array}{l}0.412^{*} \\
(0.231)\end{array}$ & $\begin{array}{l}0.279 * \\
(0.158)\end{array}$ & $\begin{array}{l}0.555^{*} \\
(0.317)\end{array}$ \\
\hline FAM & $\begin{array}{l}0.424^{*} \\
(0.227)\end{array}$ & $\begin{array}{c}0.498 * * \\
(0.235) \\
\end{array}$ & $\begin{array}{c}0.721 * * \\
(0.333) \\
\end{array}$ \\
\hline FIN & $\begin{array}{l}-1.897 \\
(2.194)\end{array}$ & $\begin{array}{l}-2.863 \\
(3.002)\end{array}$ & $\begin{array}{l}-10.897 \\
(7.361)\end{array}$ \\
\hline GRO & $\begin{array}{c}0.643 \\
(0.479)\end{array}$ & $\begin{array}{c}0.796 \\
(0.509)\end{array}$ & $\begin{array}{c}0.093 \\
(0.575)\end{array}$ \\
\hline TUR & $\begin{array}{c}-0.126 \\
(0.235) \\
\end{array}$ & $\begin{array}{l}-0.336 \\
(0.305)\end{array}$ & $\begin{array}{l}-0.126 \\
(0.235)\end{array}$ \\
\hline ROA & $\begin{array}{c}0.124 \\
(1.987)\end{array}$ & $\begin{array}{l}-0.623 \\
(2.490)\end{array}$ & $\begin{array}{l}-0.308 \\
(3.953)\end{array}$ \\
\hline LEV & $\begin{array}{c}0.747 \\
(1.173)\end{array}$ & $\begin{array}{c}1.306 \\
(1.290)\end{array}$ & $\begin{array}{c}0.447 \\
(1.764)\end{array}$ \\
\hline CAS & $\begin{array}{c}0.985 \\
(0.796)\end{array}$ & $\begin{array}{c}1.338 \\
(0.953)\end{array}$ & $\begin{array}{c}1.865 \\
(1.437)\end{array}$ \\
\hline $\begin{array}{c}\text { Audit Time, } \\
\text { Industry and Other } \\
\text { Virtual Variables } \\
\text { and Constants }\end{array}$ & Include & Include & Include \\
\hline Sample Number & 269 & 257 & 186 \\
\hline Chi-squared & 49.78 & 50.14 & 47.49 \\
\hline $\mathrm{R} 2$ & 0.235 & 0.258 & 0.269 \\
\hline
\end{tabular}

Note: $* * *, * *, *$ respectively, said in $0.01,0.05,0.10$ of the significant level.

\section{Conclusions}

The establishment of the Second Board helps to speed up change in the pattern of economic development and the effective use of resource allocation function. It shall encourage more people to 
engage in innovative and entrepreneurial activities. It would therefore help to promote the Effectiveness of IPO Approval in GEM.

\section{Summary}

The paper includes five parts. The first part introduces the origin of Chinese GEM. The second part reviews the differences between Chinese IPO approval and other countries'. The third part mainly analyzes the development of the NASDAQ. The fourth part is the focal point of the whole paper, which analyzes the determinants of IPO approval in China GEM based on the attributes of the regulatory body, the underwriter, the issuer, and assesses the impartiality and effectiveness of the process. The fifth part summarizes the main research results.

\section{Acknowledgements}

This work was financially supported by the Philosophy and Social Science Planning Project of Tianjin, the project No. is TJGL13-026.

\section{References}

[1] Dewenter K L, Field L C. "Investment Bank Reputation and Relaxed Listing Requirements: Evidence from Infrastructure Firm IPOs in Hong Kong”. Pacific- Basin Finance Journal, No.9 (2001)

[2] Doyle and William M. "Capital structure and the financial development of the U.S.” Journal of Economic History, No 3 (2000)

[3] Li G. “Test CSRC's Ability to Select Private-Owned Enterprises for IPO”. International Conference on E- Business and Information System Security, Wuhan (2009)

[4] Shi C. "Competition in China's Securities Market: Reform of Current Regulatory System.” Loyola University Chicago International Law Review, No.3 (2005)

[5] Mahérault L. "The Influence of Going Public on Investment Policy: An Empirical Study of French Family- Owned Businesses”. Family Business Review, No.13 (2000)

[6] Jog V, McConomy B J. "Voluntary Disclosure of Management Earnings Forecasts in IPO Prospectuses.” Journal of Business Finance \& Accounting, No.20(2003).

[7] Macey J R, O’Hara M. “The Economics of Stock Exchange Listing Fees and Listing Requirements”. Journal of Financial Intermediation, No.11 (2002) 